\title{
How Do Faculty Members Perceive Their Transformational Leaders?: The Case of State Universities in the Philippines
}

\author{
Leomar C. Miano, PhD \\ Faculty, College of Administration, Business, Hospitality, and Accountancy \\ Southern Luzon State University \\ Lucban, Quezon
}

Corresponding author details: Leomar C. Miano,PhD; leoamr_miano@yahoo.com

\begin{abstract}
This paper investigated how faculty members from the state universities in the Philippines perceive their transformational leaders. 324 faculty members from state universities in Luzon, Visayas, and Mindanao participated in the study. The sample size was determined using G-power with a 95\% level of confidence indicating a 5\% margin of error. This study used quantitative-descriptive design; only descriptive statistic was used to determine the perception of faculty members about their transformational leaders. This research utilized a self-constructed assessment instrument formatted on a 4-point scale and went through validation with a Cronbach Alpha of 0.907 . The result showed that faculty members perceived their transformational leaders as good with an overall mean of $3.15(\mathrm{SD}=0.54)$. They perceived their leaders as an influencer, motivator, stimulator, and considerate. Moreover, considering each indicator in transformational leadership, the faculty members perceived their leaders as good in individualized consideration with a mean of 3.18 $(\mathrm{SD}=.50)$, same with inspirational motivation with a mean of $3.22(\mathrm{SD}=.52)$, and intellectual stimulation with a mean of $3.13(\mathrm{SD}=.56)$, and individual consideration with a mean of $3.09(\mathrm{SD}=.54)$. The results revealed that those respondents from the state universities perceived their leaders as transformational. The results revealed that those respondents from the state universities perceived their leaders as transformational. This implies that the faculty members perceived their leaders with good leadership styles. Therefore, it recommends that leaders may continuously embody the characteristic of being transformational leaders to adapt and thrive to the changing needs of academic institutions due to globalization and technological advancement.
\end{abstract}

Keywords: transformational leadership; faculty members; state universities; assessment; perception

\section{INTRODUCTION}

The world is changing at an incredibly rapid pace which means that any institution must respond to the changes more quickly. Globalization and technology are few incessant changes that cannot be avoided. The twenty-first century transformed the landscape of higher education institutions (HEI) and has become multifaceted, making it essential for universities and colleges to develop savvy leaders who can effectively lead the faculty, staff, and students (Wang and Sedivy-Beton, 2016). Therefore, leadership plays a critical indicator of the success, mediocrity, or failure of any institution. According to Gigliotti and Ruben (2017), the case of higher education is no less of any institution, where the impact of leaders is critical to the effectiveness of HEI. Furthermore, Manansala (2015) stated that redesigning the present due to the constant flux of the world is vital to meet the exigencies brought by myriad changes with the vision of the future. Institution of higher learning is no exemption in the challenges brought by the rapid change of the world. Hence, tertiary education must respond and adjust quickly to the changes brought by globalization and technology.

Leadership in higher educational institutions has taken an important role in transforming the institution in the new landscape to address evolving issues and challenges brought by the rapid change in the educational setting because of internalization and technological advancement. Kinkead (2006) stated that transformational leadership is prevalent and has a significant impact on educators and the educational system.

According to Manansala (2015), the institution of higher learning should transform to become a noble institution for learning. The leaders of higher education institutions should align their policies and regulations to give remedy to an ailing system of education. The State Universities and Colleges in the Philippines need a visionary leader so that they could reform the institution to have a positive impact on the educational system. Moreover. the faculty members of an institution of higher learning should understand the importance of having a transformative leader to bring great effect to the entire educative system.

The faculty members are the front liners in the institution of higher learning and play a significant role in the success of the institutions. Knowing whether faculty members are satisfied with their leaders is vital to increase support to the administration - support that is necessary for the leaders to attain their strategic objectives. Although leadership style specifically transformational leadership is widely researched, there is no research conducted yet in this particular leadership style in the state universities in the Philippines. 
This study measures faculty members' perceptions of their transformational leaders whether they empower and inspire followers, lead charismatically, and produce faculty members with the same capability as the leader.

\section{REVIEW OF LITERATURE \\ Transformational Leadership}

Transformational leadership is a type of leadership that gives due consideration to the captain's achievements as well as his or her traits, along with communal dealings. Transformational leadership is credited for redirecting personal expectations towards institutional wellness (Dubrin, 2010). Moreover, Greenberg (2010) stated that transformational leaders revitalize the society or organization. This type of leadership is concerned with creating changes in various ways. According to Kinicki and Williams (2011) and Bateman and Snell (2015), transformative headship reshapes workers into following institutional targets beyond individual ambitions. The agenda in empowering members is to nurture them into captains. Transformative headship induces production through a range of techniques and it incites group members to realize extraordinary outcomes (Robbins \& Coulter, 2012). This takes the form of streamlining the individual perceptions and institutional goals, role-modeling, among others. Besides, Schermerhorn (2013) maintained a similar opinion when he acknowledged the exceptional attempts that can be awakened by transformative governance. Such leadership inculcates inventiveness and alterations (Daft, 2010) and the headship is known for cheering and helping others, along with emphasizing morality (Metwally \& El-bishbishy, 2014).

Transformational leaders not only satisfy their followers' needs but also generate a convenient work environment by encouraging as well as challenging their followers into devising remedies for several hardships (Claudine, 2015). Transformative headship is typical of superior foresight, articulate administration, plus stunning coordination abilities, all which are employed to set up robust ties of attachment within a group. More so, this headship of reference is popular at achieving changes due to the powerful sentimental connections it creates with and among members, thus redirecting the members' inclination towards the headship's mission (Hughes, Ginnett \& Curphy, 2012, p. 590).

Transformational headship is founded greatly on the captain's relocation of the perception and opinions of the group members.

Such captains or leaders understand the importance of qualifying together with uplifting those they lead. According to Luthans (2011), change-oriented captains are fond of idealism, inspiration, motivation, paired with personified thoughtfulness. Reza (2019), added that such heads analyze the potentials of each follower in contributing to the overall goals, thus the heads capitalize on insightful broad aims for the institution at large.

Denmark (n.d.) posited that the elements of transformation can be spotted within the centers for training in various ways. Among these are; refined learning environment, soared learners' performance, extended stakeholder participation, intensive instruction, and clear channels of transmitting the information. Irrespective of the administrative board, physical location, or structure of the low achieving school, ordinary convictions accord the necessity of steering innovations on the shoulders of the institutional head. Much as this carries some truth, initiating change needs teamwork to achieve long-term results. In the above case of the institution, change-oriented governance is the work of every instructor within the entity.
Change-oriented governance connotes intricate procedures which are believed to unite the headship with the group members to initiate change within the group, institution, or on wider coverage (Rowe \& Guerero, 2010). Changeoriented governance influences its followers' conventions as a way of awakening morality, attention, and supplies towards institutional modification (Yukl, 2010). He went ahead to underline the contrast between the theories of Bass and Burn about transformative headship. Whereas Bass quoted it as being institutional objective-oriented, Burn branded it as civic-change oriented. Even though several theories about change-oriented headship prevail, a few of them (foursome) are validated (Bass, 1997). They are explained below.

1) Idealized influence: denotes the capacity to build trust within a captain alongside cheering him or her, thus laying grounds for immense institutional alterations. The absence of this trust is bound to result in hostility to any of the captain's attempts.

2) Inspirational motivation: this potentiality certifies a captain as one who can model inspiration among group members towards the desired end. Considering occasions of instigating alterations within an institution, it falls upon the captain to induce the group members to comply with the innovation. Thus, change-oriented captains ought to be stimulative.

3) Intellectual stimulation: expertise in its varied forms within transformative headship plays a crucial role in change-endeavors. Change-oriented headship awakens the energies within its followership concerning inventiveness and its insights revision of prevailing systems. For such, there lingers a probability of obtaining constructive opinions from group members to address certain hardships

4) Individualized consideration: this concerns the distinctive assessment of each follower. Incorporating each member aboard the change procedures in an institution signifies an urgency of diagnosing the ambitions and conventions of each member and relocating them to the desired channels. Such an event helps in preserving the mission objectives of the headship. To this end, change-oriented leaders ought to understand the source of inspiration to the individual member since people's tastes and preferences differ. It follows that leaders with the ability to master these differences have a great deal of capital to invest in the change process.

Based on Robles (2012), a person's high-tech expertise remains insufficient in the current era where special traits are extremely esteemed. The need keeps rising for people with certain attributes like efficiency in information exchange because these people are anticipated to perform in the prevailing aggressive job market (Lazarus, 2013). Headship identity or its description accords the head officers firm ground to utilize as well as to improve the expertise needed in associating with others (Mencl, Wefald, \&Van Ittersum, 2016).

With no objection, nurturing institutional credence along with personal confidence rank as crucial attempts concerning institutional governance. Even though, sustaining this credence or confidence looks like a taxing venture (Savolainen, 2011). In this situation, promoting cooperation and healthy work connections within the entire institution can be a saving edge (Yukl, 2010). Credence incorporates others and encourages improvements such as those vital to learning institutions (Savolainen, 2011). 
In line with this, heads of education centers are therefore in a position to set up schemes for improving the instructors' performance and ultimately learners' achievement (Reeves, 2012; Sursock \& Howard, 2010). Advisory along with schemes for teachers' improvement in performance comprise the important elements within the teacher-achievement package throughout all educational functioning (Wasserstein, Quistberg, \& Shea, 2007). An institution under such headship takes its members above personal ambitions using influential propaganda, motivation, in sighting, among other methods.

Yukl (2010) underlined the contrast between the theories of Bass (1985, 1996) and Burn (1978) about transformative headship. Whereas Burn branded it as a civic-change-oriented type, Bass quoted it as being institutional objective-oriented. Even though several theories about change-oriented (transformative) headship prevail, a few of them (foursome) are validated (Bass, 1997). They are paraphrased as; (a) transfigured control, (b) inciteful inducement, (c) awakening of the intellect, and (d) personalized contemplation.

\section{METHODOLOGY}

This study was quantitative-descriptive mainly sought the perception of faculty members on their transformational leaders. Before the actual data gathering, the preassessment was given to faculty members to determine whether the leaders from state universities' subject of the study was transformational. The research populace for consideration was teaching personnel from different state universities in the Philippines. The inclusion criterion for participation in the study included regular faculty members only. The study included 324 respondents, one in each state university from the main island of the Philippines (Luzon, Visayas, and Mindanao). This study used G-power as the basis for the computation of sample size using the $95 \%$ level of confidence indicating a $5 \%$ margin of error, at last, the population-representative proportion estimate was 311 with an actual power of the test of $95.02 \%$. This study included a total size of 324 which exceeded the recommended sample size of 311 from G-power analysis.

Driven by the need of attaining the study's intention, the researcher used a questionnaire that was personally developed and underwent expert validation. The comments and suggestions of the experts received consideration as reflected in the revised version before administering it in a research trial within one of the state universities in Quezon Province. All of the questions were excellent which indicates that all of the questions were reliable and consistent. According to Glen (2014), scores that are above 0.7 are tolerable. Nonetheless, other authors propose elevated figures between or 0.9-0.95. The principle in explaining alpha tests for Linkert scales is shown in the table.

TABLE 1: Cronbach Alpha Table

\begin{tabular}{lllcl}
\hline & $\begin{array}{c}\text { Variables } \\
\text { (Transformational Leadership) }\end{array}$ & Number of Items & Cronbach Alpha & Verbal Interpretation \\
\hline 1. & Individualized Influence & 7 & .945 & Excellent \\
2. & Inspirational Motivation & 7 & .962 & Excellent \\
3. & Intellectual Simulation & 7 & 9.52 & Excellent \\
4. & Individual Consideration & 7 & .942 & Excellent \\
\hline
\end{tabular}

Questions in transformational leadership include individualized consideration, intellectual stimulation, individualized influence, and inspirational motivation. Questions 1-4 were adapted but modified from Leaply-Portscheller (2008) and questions 5-7 were from the Multifactor Leadership Questionnaire (OCAI). Questions were measured on a 4 Likert scale as shown in the table.

TABLE 2: Interpretation table for Organizational Culture

\begin{tabular}{cccc}
\hline Scale & Mean Interval & Scale Response & Verbal Interpretation \\
\hline 1 & $1.00-1.49$ & Strongly Disagree & Very Poor \\
2 & $1.50-2.49$ & Disagree & Poor \\
3 & $2.50-3.49$ & Agree & Good \\
4 & $3.50-4.00$ & Strongly Agree & Very Good \\
\hline
\end{tabular}

\section{ETHICAL CONSIDERATION}

This quantitative inquiry considered the advantages together with the price of the whole project. the study took into account the benefits and costs of this research. To comply with the moral security of each respondent's requirements, the investigator secured Adventist University of the Philippines Ethical Review Board (ERB) authorization no. 2019-ERBAUP-022, before information gathering in the field.

\section{RESULTS AND DISCUSSION}

The perception of faculty members on their transformative leaders in state universities within the Philippines was measured following the forms of individualized influence, inspirational motivation, intellectual stimulation, and individual consideration, and the results are presented according to individual dimensions under transformational leadership

\section{- Individualized influenced}

Statistics for transformational leadership, in terms of individualized influence, are presented in table 3. As perceived by respondents, the descriptive results based on a grand mean of $3.18(\mathrm{SD}=.50)$ revealed that the individualized influence by the leaders to faculty members from state universities is good. The highest mean under the individualized influence are: items 1 "Trust my abilities," with a mean of 3.29 (SD= .63); item 2 "Display a sense of power and confidence," having a 3.26 average, $(\mathrm{SD}=.57)$; and item 3 "Act in ways that build respect," having a 3.23 average, $(\mathrm{SD}=.65)$. In contrast, item 7 which is "Associate themselves to me," has the least average $(3.11, \mathrm{SD}=.60)$. Moreover, amongst all the items asked, faculty members agreed that the leaders from state universities practice individualized influence. 
Al-Mansoori and Koc (2019) argued that followers of one tertiary institution within the US together with another in the Middle East believed that their leaders greatly impact their followership in terms of credence along with reliance. To the followership, such heads manifest the broad intent then stimulate them into working above individual anticipations in a bid to arrive at the most elevated capacity. The faculty members, too, showed contentment arising from the granted freedom. Moreover, Alqataweh (2018) concluded that in the Jordanian Insurance Companies, the moderate idealized influence was registered, recorded to be 3.38. This also reflects headship features of moderate character with expertness, while connections amidst controlling leaders with employee's manifest credence together with integrity under average levels. Furthermore, the study conformed with the findings of Beunvinida and Ramos (2019) that individualized influence was highly observed among school heads in the Philippines. It was also further discussed by Sosik and Jung (2010) that transformative leaders communicate and cooperate with followers, and with the diverse environment, gain respect, empower others to act, and encourage and support solutions when there are difficulties.

TABLE 3: Descriptive Results of Transformational Leadership in terms of Individualized Influence

\begin{tabular}{clcccc}
\hline No. & \multicolumn{1}{c}{$\begin{array}{c}\text { Individualized Influence } \\
\text { The leaders of my organization }\end{array}$} & M & SD & SR & VI \\
\hline $\mathbf{1}$ & Trust my abilities & 3.29 & .63 & Agree & Good \\
$\mathbf{2}$ & Display a sense of power and confidence. & 3.26 & .57 & Agree & Good \\
$\mathbf{3}$ & Act in ways that build respect. & 3.23 & .65 & Agree & Good \\
$\mathbf{4}$ & Make others feel good to be around me. & 3.15 & .63 & Agree & Good \\
$\mathbf{5}$ & Instill pride in me for being associated with him or her. & 3.13 & .64 & Agree & Good \\
$\mathbf{6}$ & Go beyond self-interest for the good of the group. & 3.12 & .71 & Agree & Good \\
$\mathbf{7}$ & Associate themselves to me. & 3.11 & .60 & Agree & Good \\
& OVERALL MEAN & $\mathbf{3 . 1 8}$ & $\mathbf{. 5 0}$ & Agree & Good \\
\hline
\end{tabular}

Legend: 1) 1.00-1.49=Very Poor, 2) 1.50- 2.49= Poor, 3) 2.50-3.49=Good, 4) 3.50- 4.00= Very Good, SR= Scale Response, $V I=$ Verbal interpretation

\section{- Inspirational Motivation}

Statistics related to transformational leadership, in terms of inspirational motivation, are presented in Table 4. The descriptive results based on the grand mean of 3.22 (SD= .52) revealed that the respondents from state universities' grand scale response is agree and it is interpreted that leaders' inspirational motivation is good as perceived by faculty members. The highest mean under inspirational motivation are item 1 "Talk optimistically about the future," with a 3.31 average, $(\mathrm{SD}=.60)$; item 2 "Talk Enthusiastically about what needs to be accomplished," having a 3.27 average, $(\mathrm{SD}=.56)$; as well as item 3 "Articulate a compelling vision for the future," with a 3.26 average, $(\mathrm{SD}=0.59)$. However, the lowest mean is item 7, "Help me find meaning in my work," with a mean of 3.12 (SD=0.68), which is still categorically agreed. All of the mean scores under this dimension revealed that the faculty members perceived their leaders as having good inspirational motivation.

This is supported by Alqatawenh (2018) who concluded that within Jordan's firms for indemnity, inciteful inducement landed at 3.35, indicating an average prevalence of the inducement. Organizational heads endeavor to level up with changes together with improvements in deliberate schemes, yet also organizational heads work towards motivating their employees with commendations. According to Buenvinida and Ramos (2013) that school heads established good culture and morale and inspire the teachers to incessantly improve themselves as excellent educators

TABLE 4: Descriptive Results of Transformational Leadership in terms of Inspirational Motivation

\begin{tabular}{clcccc}
\hline No. & \multicolumn{1}{c}{$\begin{array}{c}\text { Inspirational Motivation } \\
\text { The leaders of my organization }\end{array}$} & M & SD & SR & VI \\
\hline $\mathbf{1}$ & Talk optimistically about the future. & 3.31 & .60 & Agree & Good \\
$\mathbf{2}$ & Talk Enthusiastically about what needs to be accomplished. & 3.27 & .56 & Agree & Good \\
$\mathbf{3}$ & Articulate a compelling vision for the future. & 3.26 & .59 & Agree & Good \\
$\mathbf{4}$ & Motivate everyone what must be done. & 3.24 & .66 & Agree & Good \\
$\mathbf{5}$ & Express with a few simple words what could and should be done. & 3.21 & .60 & Agree & Good \\
$\mathbf{6}$ & Provide appealing images about what followers can do. & 3.13 & .65 & Agree & Good \\
$\mathbf{7}$ & Help me find meaning in my work. & 3.12 & .68 & Agree & Good \\
& OVERALL MEAN & $\mathbf{3 . 2 2}$ & $\mathbf{. 5 2}$ & Agree & Good \\
\hline
\end{tabular}

Legend: 1) 1.00-1.49=Very Poor, 2) 1.50- 2.49=Poor, 3) 2.50- 3.49=Good, 4) 3.50- 4.00=Very Good, SR = Scale Response, $V I=$ Verbal interpretation

\section{- Intellectual stimulation}

The transformation leadership in terms of intellectual stimulation is presented in Table 5. The descriptive result based on the grand mean of $3.13(\mathrm{SD}=0.56)$ revealed that the respondents from the state universities perceived their leaders with good intellectual stimulation.
The highest mean under intellectual stimulation are: item 1 "Seek differing perspectives when solving problems," with a mean of 3.17 ( $\mathrm{SD}=0.63$ ); item 2 "Suggest new ways of looking at how to complete assignments," having a 3.15 average, $(\mathrm{SD}=.63)$; item 3 "Re-examines the appropriateness of critical assumptions," 
with a mean of $3.14(\mathrm{SD}=0.66)$, item 4 "Evaluate problems from different facets," with a mean of $3.14(\mathrm{SD}=0.64)$, and item 5 "Enable me to think about old problems in new ways," with 3.14 as its mean, $(\mathrm{SD}=0.67)$ which is agreed in the scale response.

It indicates that respondents from state universities perceived their leaders with good intellectual stimulation. All mean scores under this dimension revealed that faculty members perceived their leaders as having reasonable limits in the challenges, risks, and taking ideas from their subordinates. The present study is in contrast with the study of Al-Mansoori and Koc (2019) because they concluded that intellectual stimulation was one of the lowest among the other traits of the leaders of one tertiary institution within the US together with another in the Middle East, while in the present study, the faculty members perceived their leaders' generating of new opinions, stimulating a soaring measure of investigative reasoning, and showing esteem towards imaginative expressions. Furthermore, Alqatawenh (2018) concluded that intellectual inducement went up to 3.23 , confirmation of the average presence of inducement if the intellect within Jordan's firms for indemnity as head official's lookout for modern schemes for problem-solving as well as moving workers into creative thinking. However, in the study of Beunvinida and Ramos (2019), all indicators according to intellectual stimulation are highly observed; it indicates that schools were good role models to the teachers. Green (2013) emphasized that leading people means being a role model who influences others and lets them do good things.

TABLE 5: Descriptive Results of Transformational Leadership in terms of Intellectual Stimulation

\begin{tabular}{lllllll}
\hline No. & \multicolumn{1}{c}{$\begin{array}{c}\text { Intellectual Stimulation } \\
\text { The leaders of my organization... }\end{array}$} & M & SD & SR & VI \\
\hline $\mathbf{1}$ & Seek differing perspectives when solving problems. & 3.17 & .63 & Agree & Good \\
$\mathbf{2}$ & Suggest new ways of looking at how to complete assignments. & 3.15 & .63 & Agree & Good \\
$\mathbf{3}$ & Re-examines the appropriateness of critical assumptions. & 3.14 & .66 & Agree & Good \\
$\mathbf{4}$ & Evaluate problems from different facets. & 3.14 & .64 & Agree & Good \\
$\mathbf{5}$ & Enable me to think about old problems in new ways. & 3.14 & .67 & Agree & Good \\
$\mathbf{6}$ & Let me rethink ideas that they had never questioned before. & 3.09 & .65 & Agree & Good \\
$\mathbf{7}$ & $\begin{array}{l}\text { Provide me with profound yet new ways of unraveling perplexed } \\
\text { concepts and ideas. }\end{array}$ & 3.07 & .66 & Agree & Good \\
& OVERALL MEAN & $\mathbf{3 . 1 3}$ & $\mathbf{. 5 6}$ & Agree & Good \\
\hline
\end{tabular}

Legend: 1) 1.00-1.49=Very Poor, 2) 1.50- 2.49= Poor, 3) 2.50-3.49=Good, 4) 3.50- 4.00= Very Good, SR= Scale Response, $V I=$ Verbal interpretation

\section{- Individualized consideration}

Table 6 presents transformational leadership in terms of individualized consideration. As indicated in Table 21, the descriptive result based on the grand mean of 3.09 (SD= 0.61 ) revealed that the respondents from state universities perceived their leaders with good individualized consideration. The highest mean under individual consideration are item 1 "Help me develop my strengths," with a mean of $3.22(\mathrm{SD}=0.72)$; item 2 "Help me develop myself," with a mean of 3.16 (SD= 0.69); item 3 "Consider my needs, abilities, and aspirations of others," with a mean of 3.08 (SD= 0.73); and item 4 "Let me know how they think they are doing," with a mean of $3.08(S D=0.67)$ which is agreed in the scale response, and it is interpreted that faculty members from state universities perceived their leaders with good individualized consideration. All mean scores under this dimension revealed that faculty members perceived their leaders as having a good manner in addressing each followers' needs.
In contrast, the result of the study conducted by Al-Mansoori and Koc (2019) concluded that the faculty members felt that their leaders were not concerned about developing innovative skills at a certain tertiary institution in the US. It was also revealed that appropriate practices for cultivating inventiveness among highly overloaded academic staff in face of low instructional resource dispensation are areas that leaders should empathize on, and the faculty members were not satisfied with how their leaders interact with them. However, the present study shows that the faculty members perceived their leaders as seeking to initiate and create a direct connection with them, though it was not highly felt and observed. Mangulaban and Vargas (2021) that school heads act like mentors and coaches, and use individual approaches to each subordinate and tolerate individual differences. Moreover, Muenjohn and Armstrong (2015) stated that school leaders establish quality relationships among subordinates through individualized consideration by providing individual approaches to every teacher such as understanding individual differences, giving special treatment, and valuing each teacher.

TABLE 6: Descriptive Results of Transformational Leadership in terms of Individual Consideration

\begin{tabular}{clcccc}
\hline No. & \multicolumn{1}{c}{$\begin{array}{c}\text { Individualized Consideration } \\
\text { The leaders of my organization }\end{array}$} & M & SD & SR & VI \\
\hline $\mathbf{1}$ & Help me develop my strengths. & 3.22 & .72 & Agree & Good \\
$\mathbf{2}$ & Help me develop myself. & 3.16 & .69 & Agree & Good \\
$\mathbf{3}$ & Consider my needs, abilities, and aspirations of others. & 3.08 & .73 & Agree & Good \\
$\mathbf{4}$ & Let me know how they think they are doing. & 3.08 & .67 & Agree & Good \\
$\mathbf{5}$ & Treat me as followers rather than just a group member. & 3.05 & .74 & Agree & Good \\
$\mathbf{6}$ & Spend time teaching and coaching. & 3.04 & .73 & Agree & Good \\
$\mathbf{7}$ & Give personal attention to whom seem rejected. & 3.00 & .74 & Agree & Good \\
& OVERALL MEAN & $\mathbf{3 . 0 9}$ & $\mathbf{. 6 1}$ & Agree & Good \\
\hline
\end{tabular}

Legend: 1) 1.00- 1.49=Very Poor, 2) 1.50- 2.49= Poor, 3) 2.50- 3.49=Good, 4) 3.50- 4.00=Very Good, SR = Scale Response, $V I=$ Verbal interpretation 
The overall results of transformational leadership are presented in Table 7. To answer research question which delves into the extent of transformational leadership in the public institutions of higher learning as grasped by the academic staff members in terms of individualized influence, inspirational motivation, intellectual stimulation, and individual consideration. As per the grand mean of 3.15 $(\mathrm{SD}=0.54)$, results revealed that those respondents from the state universities perceived their leaders as transformational. This implies that the faculty members perceived their leaders with good leadership styles.

Tertiary institutions have received criticism because of their self-centeredness along with probable old-fashioned practices.
This explains the necessity of transformational leaders to steer change along with inventions in a bid to meet the communal expectations and hardships (Brandis, 2003). Taking into account the current study, its outcomes have connections with what Al-Mansoori and Koc (2019) tabled because it affirmed the presence of change-oriented administration with the departments of engineering at public universities in the United States. In the study of Jordanian firms for indemnity by Alqatawenh (2018), the dimension of idealized influence appeared in the first position, followed by inspirational motivation, and thereafter intellectual stimulation. Moreover, Mangulabnan and Vargas (2021) stated that school heads apply the indicators of transformational leadership such as inspirational motivation, individualized consideration, idealized behavior, and idealized attributes in managing schools.

TABLE 7: Summary of Descriptive Results of Transformational Leadership

\begin{tabular}{lcccc}
\hline \multicolumn{1}{c}{ Transformational Leadership } & M & SD & SR & VI \\
\hline Individualized Influence & 3.18 & .50 & Agree & Good \\
Inspirational Motivation & 3.22 & .52 & Agree & Good \\
Intellectual Stimulation & 3.13 & .56 & Agree & Good \\
Individual Consideration & 3.09 & .61 & Agree & Good \\
OVERALL & $\mathbf{3 . 1 5}$ & $\mathbf{. 5 4}$ & Agree & Good \\
\hline
\end{tabular}

\section{CONCLUSIONS}

As perceived by faculty members, it concludes that leaders from three state universities in the Philippines inspire and empower teachers, lead charismatically with vision, and offer leaderships that set a good example to develop followers with the same characteristics as them. This implies that the faculty members perceived their leaders with good leadership styles.

\section{REFERENCES}

[1] Al-Mansoori, R. S., \& Koç, M. (2019). Transformational Leadership, Systems, and Intrinsic Motivation Impacts on Innovation in Higher Education Institutes: Faculty Perspectives in Engineering Colleges. Sustainability, 11(15), 4072.

[2] Alqatawenh, A. S. (2018). Transformational leadership style and its relationship with change management. Verslas: teorija ir praktika, 19(1), 17-24.

[3] Bass, B. M. (1985). Leadership and performance beyond expectation. New York: Free Press.

[4] Bass, B.M. (1997), Transformational leadership: industrial, military and educational impact, London, Lawrence Erlbaum Associates.

[5] Bateman T. S. and Snell S. A. (2015). Management; Leading \& Collaborating in A Competitive world. 11ed. McGraw-Hill Education. New York.

[6] Buenvinida, L. P., \& Ramos, M. T. S. (2019). Transformational Leadership Practices of School Heads and Performance of City Schools in the Division of First District of Laguna, Philippines. PEOPLE: International Journal of Social Sciences, 4(3), 799-812.

[7] Burns, J.M. (1978) Leadership. New York. Harper \& Row

[8] Brandis, B. (2003). Transformational Leadership in Higher Education: From Politics to Porcelain. Master's Thesis, University of Northern Iowa, Cedar Falls, IA, USA.
[9] Claudine, M. S. G. (2015). The Emerging Role of Transformational Leadership. Sydney Conference, 2015, 49(6).

[10] Denmark, V. (n.d). Transformational Leadership - A Matter of Perspective.

[11] Dubrin, A. J. (2013). Leadership: Reasech Findings, Practice, and Skills ( $7^{\text {th }}$ ed.). South-Western. Cengage Learning.

[12] Gigliotti, R. A., \& Ruben, B. D. (2017). Preparing Higher Education Leaders: A Conceptual, Strategic, and Operational Approach. Journal of Leadership Education, 16, 96-114.

https://doi.org/10.12806/V16/I1/T1

[13] Glen, S. (2014). Cronbach's Alpha: Simple Definition, Use and Interpretation. From StatisticsHowTo.com: Elementary Statistics for the rest of us! https://www.statisticshowto.com/cronbachsalpha-spss/

[14] Green, Edward (2013). The Real School Leaders: 21st Century Leadership Styles. Educational Journal 5th Edition. Pp 120-135

[15] Greenberg, J. (2010). Managing Behavior in Organization (5 $5^{\text {th }}$ ed.). New Jersey: Pearson Education Inc.

[16] Hughes, R. L., Ginnett, R. C., \& Curphy, G. J. (2012). Leadership enhancing the lessons of experience $\left(7^{\text {th }}\right.$ ed.). New York: NY. McGraw-Hill/Irwin.

[17] Kinicki and Williams (2011). Management. Boston. McGraw-Hill-Irwin

[18] Kinkead, J. C. (2006). Transformational Leadership: A Practice Needed for First-Year Success. Online Submission.

[19] Lazarus, R. S. (2013). Fifty years of the research and theory of RS Lazarus: An analysis of historical and perennial issues. Psychology Press. 
[20] Leapley-Portscheller, C. I. (2008). Leadership style and adequate yearly progress: A correlational study of effective principal leadership. University of Phoenix: $A Z$

[21] Luthans, F. (2011). Organizational behavior: An evidence-based approach (12th ed.). New York: NY. McGraw-Hill/Irwin.

[22] Manansala, T. (2015). Transformational leadership behaviour skills of presidents and vice-presidents of state universities and colleges in the Philippines. Journal of US-China Public Administration, 12(5), 360-377.

[23] Mangulabnan, B., \& Vargas, D. (2021) Transformational Leadership Styles of School Principals in Central Luzon, Philippines. Rhodora And Vargas, Danilo, Transformational Leadership Styles of School Principals in Central Luzon, Philippines (March 15, 2021).

[24] Mencl, J., Wefald, A. J., \& van Ittersum, K. W. (2016) Transformational leader attributes: interpersonal skills, engagement, and well-being. Leadership \& Organization Development Journal, 37(5), 635-657.

[25] Metwally, A. H., \& El-bishbishy, N. (2014). The impact of transformational leadership style on employee satisfaction, 5(3), 3-4.

[26] Muenjohn, N., \& Armstrong, A. (2015) Transformational leadership: The influence of culture on the leadership behaviours of expatriate managers. International Journal of Business and information, 2(2).

[27] Reza, M. H. (2019). Components of Transfromational Leadership Behavior.

Httpps://www/researchgate.net/publication/3337 98276

[28] Reeves, D. B. (2012). Transforming professional development into student results. Retrieved fromhttps://books.google.com.ph/books?
[29] Robbins S. P. and Coulter M. 2012.Management. Prentice Hall. Pearson Education.

[30] Robles, M. M. (2012). Executive perceptions of the top 10 soft skills needed in today's workplace. Business Communication Quarterly, 75(4), 453-465.

[31] Rowe, W. G. \& Guerero, L. (2011) Cases in leadership $\left(2^{\text {nd }} e d\right.$ ). United State of America: USA. SAGE Publications Inc.

[32] Savolainen, T., \& Häkkinen, S. (2011). Trusted to lead: Trustworthiness and its impact on leadership. Open Source Business Resource, Retrieved from http://timreview.ca/article/429

[33] Schermerhorn J. R., JR. (2013). Introduction to Management (12 th e.d). John Wiley \& Sons Singapore Ltd.

[34] Sursock, H. S., and Howard, D. (2010). Trend 2010: A decade of change in European Higher Education. Brussels: European University Association

[35] Sosik, J.J. \& Jung, D. I. (2010). Full Range Leadership Development Pathways for People,Profit,and Planet. New York: Routledge

[36] Wang, V. C., \& Sedivy-Benton, A. L. (2016). Leadership Misplacement: How Can This Affect Institutions of Higher Education? New Horizons in Adult Education and Human Resource Development, 28, 14-25. https://doi.org/10.1002/nha3.20148

[37] Wasserstein, A. G., Quistberg, D. A., \& Shea, J. A. (2007). Mentoring at the University of Pennsylvania: results of a faculty survey. Journal of general internal medicine.

[38] Yukl, G. (2010). Leadership in organization (2nd ed.) Upper Saddle River, New Jersy. Pearson Education, Inc. 